\title{
High frequency of multidrug-resistant
} (MDR) Klebsiella pneumoniae harboring several $\beta$-lactamase and integron genes collected from several hospitals in the north of Iran

\author{
Mojgan Farhadi ${ }^{1}$, Mohammad Ahanjan², Hamid Reza Goli ${ }^{1}$, Mohammad Reza Haghshenas ${ }^{1}$ and \\ Mehrdad Gholami $i^{1,2^{*}}$
}

\begin{abstract}
Background: Klebsiella pneumoniae is one of the leading causes of hospital outbreaks worldwide. Also, antibioticresistant K. pneumoniae is progressively being involved in invasive infections with high morbidity and mortality. The aim of the current study was to determine antimicrobial susceptibility patterns and the incidence of resistance genes (integron types and $\beta$-lactamase-encoded genes) among clinical isolates of K. pneumoniae.

Methods: In this cross-sectional study, a total of 100 clinical samples were obtained from hospitalized patients in three teaching hospitals in the north of Iran, from November 2018 and October 2019. Antimicrobial susceptibility testing was performed using disk agar diffusion test in line with CLSI recommendations. For colistin, minimum inhibitory concentration (MIC) was determined using broth microdilution. Based on antibiogram, multi-drug resistant (MDR) and extensive-drug resistant (XDR) strains were detected. Finally, integron types and $\beta$-lactamase resistance genes were identified using polymerase chain reaction technique.
\end{abstract}

Results: The most and least clinical samples were related to the urine and bronchoalveolar lavage, respectively. Based on the antibiogram results, amikacin and gentamicin exhibited good activity against $K$. pneumoniae strains in vitro. The high resistance rate (93\%) to ampicillin/sulbactam predicts the limited efficacy of this antibiotic, in the hospitals studied. Among all the 100 isolates, the frequency of MDR and XDR phenotypes were $58 \%$ and $13 \%$, respectively, while no pan-drug resistant (PDR) strains were found. In the MDR K. pneumoniae strains, the prevalence of bla $a_{\mathrm{SHV},}$ bla $a_{\mathrm{TEM}}, b l a_{\mathrm{CTX}-\mathrm{M}-15}, b l a_{\mathrm{KPC}}, b / a_{\mathrm{OXA}-48}, b a_{\mathrm{NDM}} \beta$-lactamase genes were $91.4 \%, 82.7 \%, 79.3 \%, 29.3 \%, 36.2 \%$ and 6.9\%, respectively, however $91.4 \%$ of the isolates were carrying intl gene. Class II and III integrons were not detected in any isolates.

Conclusion: The MDR K. pneumoniae is becoming a serious problem in hospitals, with many strains developing resistance to most available antimicrobials. Our results indicate co-presence of a series of $\beta$-lactamase and integron types on the MDR strains recovered from hospitalized patients. The increasing rate of these isolates emphasizes the importance of choosing an appropriate antimicrobial regimen based on antibiotic susceptibility pattern.

\footnotetext{
*Correspondence: mehrdad_gholami90@yahoo.com; me.gholami@mazums.ac.ir

1 Department of Microbiology and Virology, Faculty of Medicine,

Mazandaran University of Medical Sciences, Sari, Iran

Full list of author information is available at the end of the article
} permits use, sharing, adaptation, distribution and reproduction in any medium or format, as long as you give appropriate credit to the original author(s) and the source, provide a link to the Creative Commons licence, and indicate if changes were made. The images or other third party material in this article are included in the article's Creative Commons licence, unless indicated otherwise in a credit line to the material. If material is not included in the article's Creative Commons licence and your intended use is not permitted by statutory regulation or exceeds the permitted use, you will need to obtain permission directly from the copyright holder. To view a copy of this licence, visit http://creativecommons.org/licenses/by/4.0/. The Creative Commons Public Domain Dedication waiver (http://creativeco mmons.org/publicdomain/zero/1.0/) applies to the data made available in this article, unless otherwise stated in a credit line to the data. 
Keywords: K. pneumoniae, Antibiotic resistance, Integron, $\beta$-lactamase, MDR

\section{Background}

Among the Klebsiella spp, Klebsiella pneumoniae (K. pneumoniae or KP) a gram- negative encapsulated bacterium, is responsible for up to $10 \%$ of nosocomial infections [1]. This organism causes a wide range of infections, such as pneumonia, burn and urinary tract infections (UTIs), septicemia, and meningitis [2]. Management of the infections caused by antibiotic-resistant $K$. pneumoniae is problematic due to the bacterium's intrinsic and acquired resistance to a broad spectrum of the drugs, such as $\beta$-lactams. MDR strains can be fairly challenging to treat, especially for elderly, immunosuppressed individuals, or infants with immature immunity [3]. The $\beta$-lactamase-producing $K$. pneumoniae can destroy a varied range of $\beta$-lactams such as penicillins, carbapenems, and cephalosporins [4]. The key mechanisms of resistance $K$. pneumoniae uses against these antimicrobials are hyperexpression of chromosomal cephalosporinases and production of plasmid-encoded Ambler class A [Extended spectrum $\beta$-lactamases (ESBLs)], B (Metallo$\beta$-lactamases) and $D$ (oxacillinases) $\beta$-lactamases [5]. ESBLs are plasmid-borne enzymes that hydrolyze the oxyimino $\beta$-lactam ring found in 3rd generation cephalosporins and aztreonam. The extensive use of numerous $\beta$-lactam agents in recent decades has led to the appearance of ESBLs, which are frequently derivatives of TEM-1 and SHV-1 enzymes [6]. Carbapenems are the $\beta$-lactams of choice for the treatment of infections caused by ESBL-producing K. pneumoniae. Ambler class $B$ enzymes which play a critical role in drug resistance against carbapenems, are zinc dependent and inhibited by EDTA [7]. Resistance genes have a high ability to spread, because the genes have commonly found on the transferable elements such as integrons, insertion sequences (IS) and transposons [8, 9]. Integrons, a segment of double-strand DNA sequence, are immobilized, but contain an integrase (intI)-encoding gene that allows the insertion of the resistance gene cassettes between highly conserved nucleotide sequences. Although several types of integrons have been identified, class I, II and III integrons are the most common types in the clinical settings $[10,11]$. In recent years, MDR $K$. pneumoniae strains producing ESBLs-, MBLs, and KPC resistance genes have been progressively found in many regions of Iran [12-14]. Despite the high importance of this issue, only a restricted number of reports have originated from the north of Iran addressing the frequency and coexistence of resistance genes among the clinical isolates of $K$. pneumoniae. Therefore, this study was performed to determine the antibiotic resistance profiles, incidence of MDR, XDR and PDR phenotypes and also prevalence of $\beta$-lactamase and integron resistance genes among $K$. pneumoniae strains isolated from hospitalized patients in the north of Iran.

\section{Methods \\ Study design and sampling}

In this descriptive cross-sectional study, based on the previous study [15], using the following formula $n=z^{2} P$ $(1-\mathrm{P}) / \mathrm{d}^{2}$, on a total of 100 non-duplicated samples, which were obtained from the one-year from November 2018 to October 2019. The clinical samples were collected from hospitalized patients of three educational hospitals in Mazandaran province. 1: Razi Teaching Hospital located in Qaem Shahr (Qaem Shahr is a city in Mazandaran province, in northern Iran) 2: Imam Khomeini Teaching Hospital located in Sari (Sari is the largest and the capital city of Mazandaran province, in northern Iran) and Zare Teaching Hospital located in Sari. These hospitals currently operate under the Mazandaran University of Medical Sciences (MAZUMS). The geographic region of the studied hospitals is shown in Fig. 1. One hundred K. pneumoniae isolates were recovered from different clinical sources including blood, sputum, bronchoalveolar lavage (BAL), wound exudates, urine, cerebrospinal fluid (CSF) and synovial fluid. In this study, all clinical specimens from any human source which contain $K$. pneumoniae, including both gender, and from all age groups including infants to elderly were included. Hence, K. pneumoniae strains isolated from out-patients, as well as other species of Klebsiella and mixed and/or contaminated plates were excluded.

\section{Microbiological method}

The samples were cultured on MacConkey agar (Merck, Germany), then incubated at $37{ }^{\circ} \mathrm{C}$ for $24 \mathrm{~h}$. The recovered colonies were initially identified using conventional biochemical and microbiological tests, including motility $(-)$, urease $(+)$, oxidase $(-)$, lysine decarboxylase $(+)$, citrate utilization $(+)$, Triple sugar iron agar (acid/ acid), Hydrogen sulfide (-), Methyl Red-Voges Proskauer $(-/+)$, and Indole $(-)$ [16]. Further confirmation of $K$. pneumoniae strains at the species level was accomplished by the analytical profile index (API) 20E kit (bioMérieux, La-Balme-les-Grottes, France) according to the manufacturer's instructions [17]. All isolates were preserved in the Luria-Bertani (LB) broth (Merck, Co., Germany) containing $20 \%$ glycerol at $-80{ }^{\circ} \mathrm{C}$ for further use. 


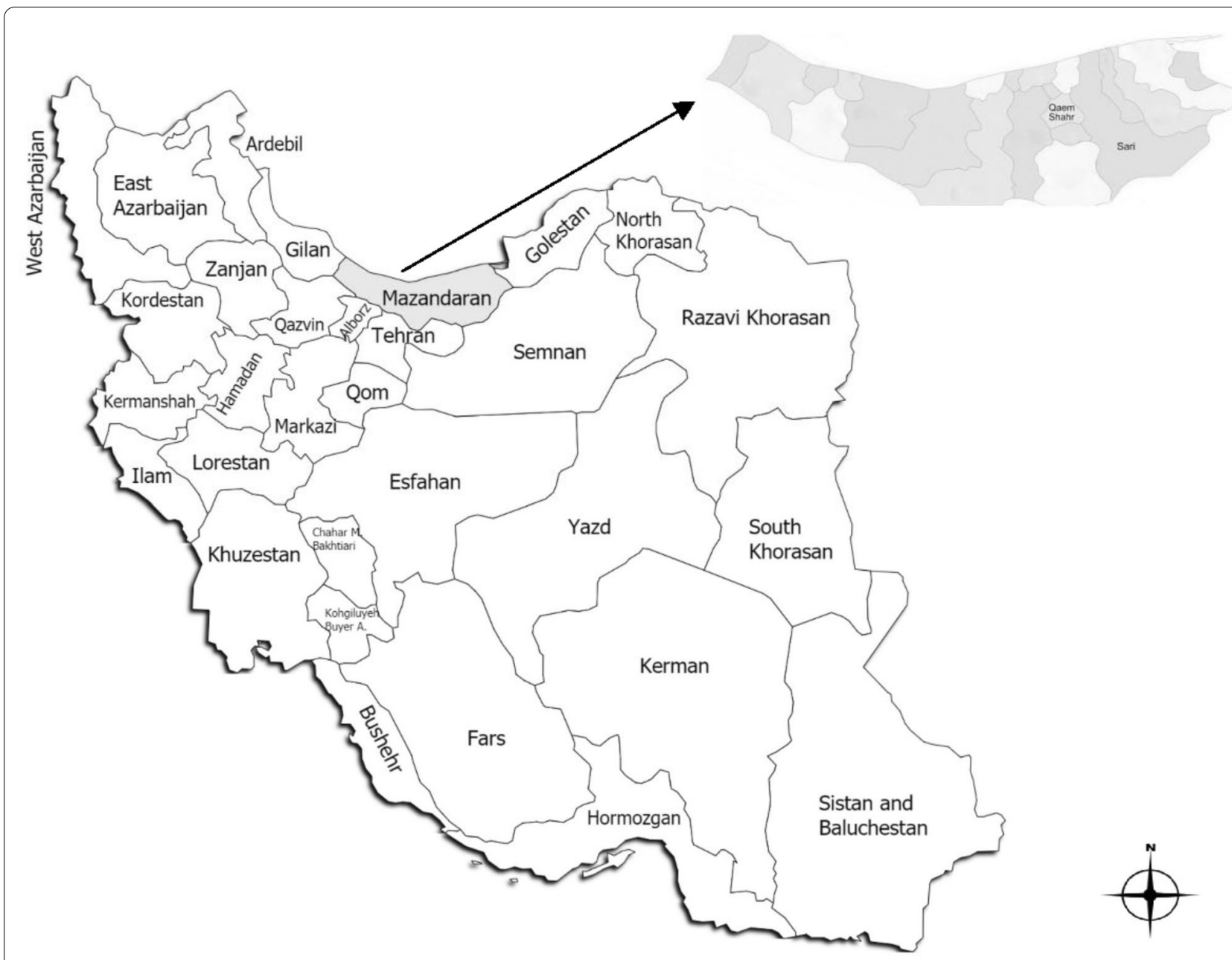

Fig. 1 Map of Iran displaying the study province (gray zone) (Mazandaran province, northern Iran), with the geographical location of the collection centers in the cities of Sari and Qaem Shahr

\section{Antimicrobial susceptibility testing (AST)}

In concordance with the Clinical and Laboratory Standards Institute; CLSI. 2018 [18], antimicrobial susceptibility testing was done on the Mueller-Hinton agar plates (Merck Co., Germany) by disk agar diffusion (DD) method against 16 following antimicrobials: levofloxacin (LEV; $5 \mu \mathrm{g})$; ceftazidime (CAZ; $30 \mu \mathrm{g})$, cefotaxime (CTX; $30 \mu \mathrm{g})$, cefepime (FEP; $30 \mu \mathrm{g})$, ertapenem (ETP; $10 \mu \mathrm{g}$ ), amikacin (AK; $30 \mu \mathrm{g})$, meropenem (MER; $10 \mu \mathrm{g})$, ceftriaxone (CRO; $30 \mu \mathrm{g})$, ampicillin/sulbactam (SAM; 10/10 $\mu \mathrm{g}$ ), cefoperazone (CFP; $75 \mu \mathrm{g}$ ), imipenem (IPM; $10 \mu \mathrm{g})$, nitrofurantoin (NIT;300 $\mu \mathrm{g}$ ), gentamicin (GM; $10 \mu \mathrm{g}$ ), ciprofloxacin (CIP; $5 \mu \mathrm{g}$ ), tetracycline (TET; $30 \mu \mathrm{g}$ ), and trimethoprim-sulfamethoxazole (SXT; $1.25 / 23.75 \mu \mathrm{g}$ ) (MAST Diagnostics, Merseyside, UK). The MDR and possible XDR/PDR strains were recognized according to the guidelines suggested by the European
Center for Disease Control and Prevention (ECDC) [19]. E. coli ATCC 25922 was used as a quality control (QC) organism. Also, colistin susceptibility assay was done for carbapenems-resistance isolates by broth microdilution method according to the European Committee on Antimicrobial Susceptibility Testing (EUCAST) breakpoints [20]. The E. coli NCTC 13846 (a colistin-resistant strain) was used as QC in colistin minimum inhibitory concentration (MIC) determination. The primary screening of extended-spectrum $\beta$-lactamases (ESBL)-producing pathogens was assess by the profile of AST. Strains that display reduced susceptibilities to $\mathrm{CAZ}$ and/or CTX were temporarily regarded as ESBL-producer, and finally confirmed as instructed by CLSI. 


\section{Genomic DNA extraction}

Total genomic DNA of every isolate was obtained from the colonies grown on the LB medium (Merck, Darmstadt, Germany) using a High Pure PCR Template Preparation Kit (Roche, Germany), based on the manufacturer's instruction. The extracted DNAs were quantified by measuring the absorbance at A260/A280 with Nanodrop spectrophotometer (ND-1000; Thermo Scientific; Wilmington, DE, USA), to evaluate the extracted DNA purity. Purified DNA was kept at $-20{ }^{\circ} \mathrm{C}$ until further use.

\section{Molecular methods}

PCR primers were designed for the detection of integrase genes (intI, intII, and intIII), and resistance elements such as $b l a_{\mathrm{CTX}-\mathrm{M}-15}, b l a_{\mathrm{TEM}}, b l a_{\mathrm{SHV}}, b l a_{\mathrm{KPC}}, b l a_{\mathrm{OXA}-48}$ and $b l a_{\mathrm{NDM}}$ genes. The primer sequences used in this work are listed in Additional file 1: Table S1, as previously described. Amplification reactions were performed in a final volume of $25 \mu \mathrm{l}$, containing $0.8 \mu \mathrm{l}$ of the extracted DNA $(0.5 \mu \mathrm{g}), 12.5 \mu \mathrm{l}$ of $2 \times$ Master Mix (Amplicon Co., Denmark), including $1 \times \mathrm{PCR}$ buffer, $1.5 \mathrm{mmol} / \mathrm{l} \mathrm{MgCl}_{2}$, dNTPs at a concentration of $0.15 \mathrm{mmol} / \mathrm{l}$ each dNTP, $1.25 \mathrm{U}$ of Taq DNA polymerase (Amplicon Co., Denmark), $0.7 \mu \mathrm{l}$ of $0.8 \mu \mathrm{M}$ of each primer, and nuclease free sterile water, up to $25 \mu$ l. The PCR mixture reaction was amplified in a Techne TC-512 thermal cycler (Eppendorf, Hamburg, Germany) as follows: initial denaturation at $95{ }^{\circ} \mathrm{C}$ for $1 \mathrm{~min}, 32$ cycles of denaturation for $30 \mathrm{~s}$ at $94{ }^{\circ} \mathrm{C}$, annealing for $30 \mathrm{~s}$ at $60^{\circ} \mathrm{C}$ and extension for $1 \mathrm{~min}$ at $72{ }^{\circ} \mathrm{C}$, and a final extension for $5 \mathrm{~min}$ at $72{ }^{\circ} \mathrm{C}$. PCR amplicon products were subjected to electrophoresis in a $1.0 \%$ agarose gel, stained with Gel $\operatorname{Red}^{\mathrm{TM}}$ (Biotium, USA) and photographed with ultraviolet illumination (Bio-rad, Hercules, USA). Both positive and negative controls were included in each run. The positive PCR products were sequenced by Bioneer Company (Korea). The nucleotide sequences alignments were analyzed with running Basic Local Alignment Search Tool (BLAST) at National Center for Biotechnology Information (NCBI) database (http://blast.ncbi.nlm.nih.gov/Blast.cgi).

\section{Statistical analysis}

After collection of the data, statistical analysis was performed with the IBM SPSS Statistics 20 (SPSS Inc., Chicago, IL, USA) and a $p$-value less than 0.05 was considered as statistically significant.

\section{Results}

\section{Bacterial isolation}

A total of 100 non-duplicated $K$. pneumoniae were obtained from blood $(n=15)$, sputum $(n=5)$, BAL $(n=2)$, wound exudates $(n=10)$, urine $(n=65)$ and CSF $(\mathrm{n}=3)$. The frequency of isolates in hospital wards were as follows: Intensive Care Units (ICUs) $(n=27)$, burn $(n=19)$, dialysis $(n=17)$, hematology-oncology $(n=12)$, respiratory care $(n=9)$, internal medicine $(n=8)$, neonatal intensive care unit (NICU) $(\mathrm{n}=5)$, and surgery $(\mathrm{n}=3)$. The mean age of the patients was 51.7 years (ranging from 15 to 91 years), where $58 \%(n=58)$ of the patients were female and $42 \%(n=42)$ of them were male. In our studied therapeutic centers, the prevalence of K. pneumoniae was as follows: $41 \%$ in Imam Khomeini, $45 \%$ in Zare and 14\% from Razi hospitals affiliated to the Mazandaran University of Medical sciences (north of Iran).

\section{Determination of antibiotic resistance pattern}

Based on the acquired antibiotic resistance pattern, the highest and lowest resistance rate was related to SAM (93\%) and AK (8\%), respectively (Table 1). Also, 58\% $(58 / 100)$ of the isolates were resistant to three or more antimicrobials (MDR), and 13\% (13/100) isolates were XDR. No PDR isolates were found. No non-MDR strains were resistant to AK. Altogether, the frequency of resistance genes among MDR strains was significantly higher than in non-MDR strains $(\mathrm{p}<0.05)$. Overall, among 45 carbapenem-resistant $K$. pneumoniae (CRKP) strains, 28 cases were resistant to colistin antibiotic with a MIC $>2$. Beside, ESBLs were phenotypically identified in 64 (64\%) of the all tested isolates, molecular analysis exhibited that all strains had at least one ESBL gene.

\section{Molecular detection of resistance genes}

Molecular analysis results showed that class I integrons were the predominant resistance transferable elements in our isolates. However, $91.4 \%$ and $11.9 \%$ of the MDR and non-MDR isolates were carrying intI gene, respectively. Class II and III integrons were not detected in any isolates. As shown in Table 2, the frequency of resistance genes in MDR isolates was higher than non-MDR. Among the MDR strains, the frequency of $b l a_{\mathrm{SHV}}$, $b l a_{\mathrm{TEM}}, \quad b l a_{\mathrm{CTX}-\mathrm{M}-15}, \quad b l a_{\mathrm{KPC}}, \quad b l a_{\mathrm{OXA}-48}, b l a_{\mathrm{NDM}}$ were $91.4 \%, 82.7 \%, 79.3 \%, 29.3 \%, 36.2 \%$ and $6.9 \%$, respectively. The agarose gel electrophoresis of the PCR-amplified products for interest genes are shown in Fig. 2. Overall, the co-existence of the $b l a_{\mathrm{SHV}} / b l a_{\mathrm{TEM}}, b l a_{\mathrm{TEM}} / b l a_{\mathrm{CTX}}$ ${ }_{\mathrm{M}-15}, \quad b l a_{\mathrm{SHV}} / b l a_{\text {CTX-M-15 }}, \quad b l a_{\mathrm{CTX}-\mathrm{M}-15} / b l a_{\text {OXA-48 }}, \quad b l a_{\mathrm{SHV}} /$ $b l a_{\mathrm{OXA}-48}, b l a_{\mathrm{TEM}} / b l a_{\mathrm{OXA}-48}$, and $b l a_{\mathrm{SHV}} / b l a_{\mathrm{KPC}}$, were $21 \%, 18 \%, 13 \%, 8 \%, 5 \%, 4 \%$, and $3 \%$, correspondingly. Only one isolate was carrying $b l a_{\mathrm{SHV}} / b l a_{\mathrm{TEM}} / b l a_{\mathrm{CTX}-\mathrm{M}-}$ ${ }_{15} / b l a_{\mathrm{KPC}} / b l a_{\mathrm{OXA}-48}$ genes.

\section{Discussion}

The increasing rate of $K$. pneumoniae resistant strains against multiple antimicrobials is a major challenge in medical centers [30]. In a systematic review and 
Table 1 Antimicrobial susceptibility pattern among MDR and non-MDR K. pneumoniae isolates

\begin{tabular}{|c|c|c|c|c|c|c|}
\hline \multirow[t]{2}{*}{ Antimicrobial agents } & \multicolumn{3}{|c|}{ No. (\%) in MDR-isolates } & \multicolumn{3}{|c|}{ No. (\%) in Non-MDR isolates } \\
\hline & $S$ & I & $\mathbf{R}$ & $\mathrm{s}$ & 1 & $\mathbf{R}$ \\
\hline LEV & $36(36 \%)$ & $3(3 \%)$ & $19(19 \%)$ & $38(38 \%)$ & $0(0 \%)$ & $4(4 \%)$ \\
\hline CAZ & $10(10 \%)$ & $7(7 \%)$ & $41(41 \%)$ & $32(32 \%)$ & $2(2 \%)$ & $8(8 \%)$ \\
\hline CTX & $11(11 \%)$ & $8(8 \%)$ & $39(39 \%)$ & $29(29 \%)$ & $4(4 \%)$ & $9(9 \%)$ \\
\hline FEP & $15(15 \%)$ & $5(5 \%)$ & $38(38 \%)$ & $36(36 \%)$ & $3(3 \%)$ & $3(3 \%)$ \\
\hline ETP & $35(35 \%)$ & $3(3 \%)$ & $20(20 \%)$ & $38(38 \%)$ & $1(1 \%)$ & $3(3 \%)$ \\
\hline AK & $45(45 \%)$ & $5(5 \%)$ & $8(8 \%)$ & 41 (41\%) & $1(1 \%)$ & $0(0 \%)$ \\
\hline MER & $17(17 \%)$ & $2(2 \%)$ & 39 (39\%) & 39 (39\%) & $0(0 \%)$ & $3(3 \%)$ \\
\hline $\mathrm{CRO}$ & $14(14 \%)$ & $6(6 \%)$ & $38(38 \%)$ & $35(35 \%)$ & $3(3 \%)$ & $4(4 \%)$ \\
\hline SAM & $1(1 \%)$ & $1(1 \%)$ & $56(56 \%)$ & $0(0 \%)$ & $5(5 \%)$ & 37 (37\%) \\
\hline CFP & 11 (11\%) & $4(4 \%)$ & $43(43 \%)$ & 32 (32\%) & $1(1 \%)$ & $9(9 \%)$ \\
\hline IPM & $26(26 \%)$ & $2(2 \%)$ & $30(30 \%)$ & 39 (39\%) & $0(0 \%)$ & $3(3 \%)$ \\
\hline NIT & $2(2 \%)$ & $3(3 \%)$ & 53 (53\%) & 25 (25\%) & $13(13 \%)$ & $4(4 \%)$ \\
\hline GM & 40 (40\%) & $1(1 \%)$ & 17 (17\%) & 35 (35\%) & $1(1 \%)$ & $6(6 \%)$ \\
\hline CIP & 31 (31\%) & $0(0 \%)$ & 27 (27\%) & 65 (65\%) & $0(0 \%)$ & $7(7 \%)$ \\
\hline TET & $22(22 \%)$ & 17 (17\%) & 19 (19\%) & 33 (33\%) & $6(6 \%)$ & $3(3 \%)$ \\
\hline SXT & 13 (13\%) & $4(4 \%)$ & $41(41 \%)$ & 31 (31\%) & $2(2 \%)$ & $9(9 \%)$ \\
\hline
\end{tabular}

MDR multidrug resistant, $S$ susceptible, I intermediate, $R$ resistant, LEV levofloxacin, CAZ ceftazidime, CTX cefotaxime, FEP cefepime, ETP ertapenem, $A K$ amikacin, $M E R$ meropenem, CRO ceftriaxone, SAM ampicillin/sulbactam, CFP cefoperazone, IPM imipenem, NIT nitrofurantoin, GM gentamicin, CIP ciprofloxacin, TET tetracycline, SXT trimethoprim-sulfamethoxazole

Table 2 Antimicrobial resistance genes and integron types in MDR and non-MDR K. pneumoniae isolates

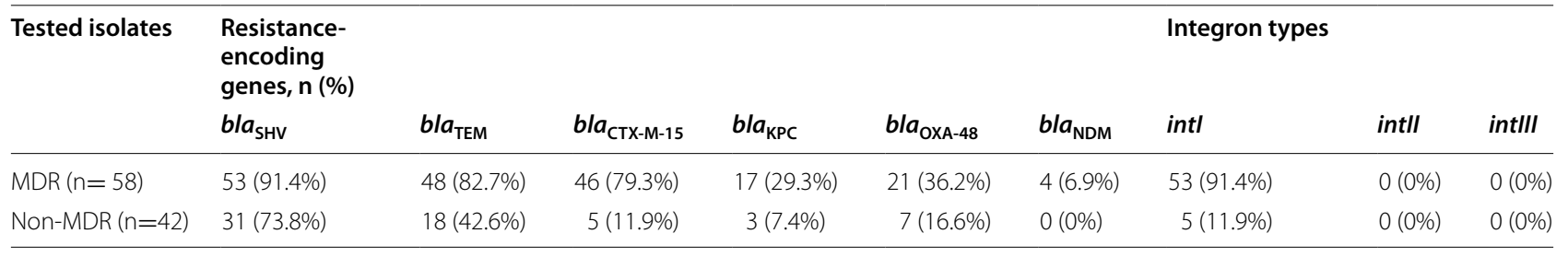

meta-analysis article, Vaez et al., (2019), declared that there is a relatively high frequent antibiotic-resistant $K$. pneumoniae in Iran [31]. In the present study, the highest and lowest resistance rates were related to SAM (93\%) and AK (8\%), respectively. In this study, 33\% of the isolates were considered as an IMP-resistant $K$. pneumoniae (IRKP); $30 \%$ of the MDR and 3\% of the non-MDR strains, while no non-MDR strains were resistant to AK. In total, only eight isolates were resistant to AK; therefore, this antimicrobial was the best choice against the tested strains. The frequency of MDR and XDR isolates in our hospitals were $58 \%$ and $13 \%$, respectively. In comparison with our data, Moghadas et al. reported that $7.5 \%, 16.1 \%, 32.9 \%, 34.1 \%, 36.4 \%$, and $42.7 \%$ of their isolates were resistant to IPM, CIP, SXT, FEP, AN, and CAZ, respectively [32]. Another study also showed disparity with our data, where $89.5 \%$ of the $K$. pneumoniae strains were MDR [33], thus far higher than reported in the current work. Geographic distance, level of hygiene, type of specimens, date of study, sample size, and restriction on antibiotic usage may be the reasons for these inconsistencies.

In our study, colistin resistance was found in $62.22 \%$ CRKP strains, which we consider a surprisingly high level. Possibly the over-use of this antimicrobial during recent years in the treatment of infections caused by organisms resistant to less toxic antibiotics could be the cause of this phenomenon. In an earlier study from Iran, Farivar et al. reported that $16.9 \%$ of $K$. pneumoniae isolated from various clinical sources were resistant to colistin [34]. In another recent work performed in an Iranian teaching hospital involving 100 CRKP strains from hospitalized patients, $50 \%$ of them were resistant to colistin [35]. Previous reports from India, Kuwait, Turkey and United Arab Emirates revealed that the prevalence of colistin resistance among $K$. pneumoniae was $4 \%, 8 \%$, 


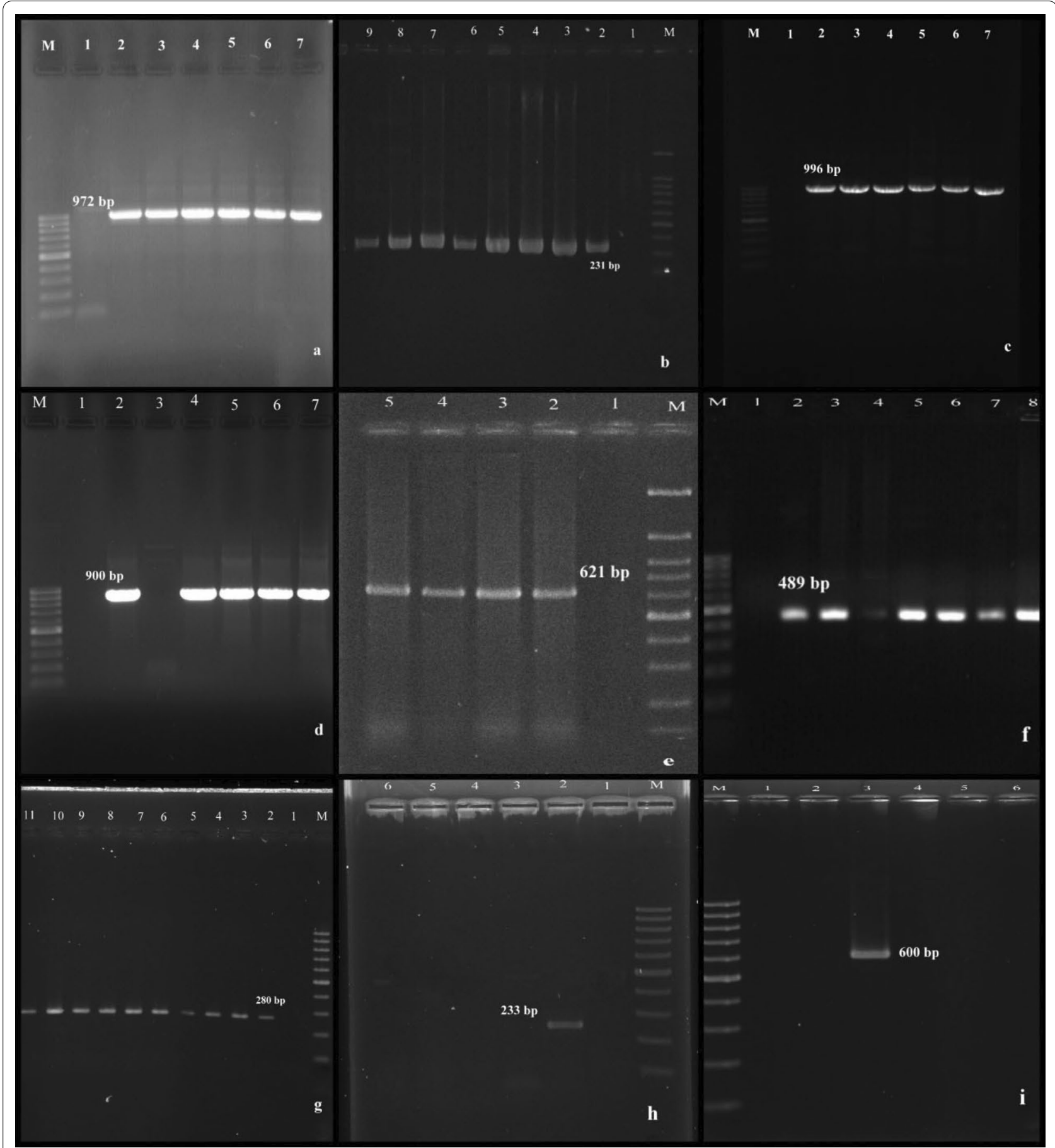

Fig. 2 Agarose gel electrophoresis used for separation of the different PCR products. Lanes labeled "M-" correspond to ladder $100 \mathrm{bp}$. Lanes labeled "1" correspond to negative controls in multi-panel figures. Lanes labeled "2" correspond to positive controls in multi-panel figures; a amplified products of bla $a_{T E M}(972 \mathrm{bp}), \mathbf{b} b / a_{\mathrm{SHV}}(231 \mathrm{bp}), \mathbf{c} b / a_{\mathrm{CTX}-\mathrm{M}-15}:(996 \mathrm{bp}), \mathbf{d}$ bla $a_{\mathrm{OXA}-48}(900 \mathrm{bp}), \mathbf{e} b / a_{\mathrm{NDM}}(621 \mathrm{bp}), \mathbf{f} b a_{\mathrm{KPC}}(489 \mathrm{bp}), \mathbf{g} \mathrm{intl}(280 \mathrm{bp}), \mathbf{h}$ intll (233 bp) and lane $\mathbf{i}$ int/ll (600 bp)

27.5\%, and 31.4\% [36-39]. Molecular analysis showed that the frequency of resistance genes in MDR isolates was higher than non-MDR ones. In our study, out of 58 MDR K. pneumoniae, intI, bla $a_{\mathrm{SHV}}, b l a_{\mathrm{TEM}}, b l a_{\mathrm{CTX}-\mathrm{M}-15}$, $b l a_{\mathrm{OXA}-48}, b l a_{\mathrm{KPC}}, b l a_{\mathrm{NDM}}$ were detected in $91.4 \%$, $91.4 \%, 82.7 \%, 79.3 \%, 36.2 \%, 29.3 \%$ and $6.9 \%$ of them by PCR. Mahmoudi et al. showed that out of $30 \mathrm{~K}$. pneumoniae isolates, the frequency of $b l a_{\mathrm{SHV}}, b l a_{\mathrm{CTX}-\mathrm{M}-15}$ and 
$b l a_{\text {TEM }}$ genes were $83 \%(\mathrm{n}=25), 70 \%(\mathrm{n}=21)$ and $57 \%$ $(\mathrm{n}=17)$, respectively [40]. In another study, directed by Ghafourian et al., (2012), 36.1\% (104/288), 7.6\% (22/288) and $5.9 \%(17 / 288)$ of $K$. pneumoniae isolates in patients with urinary tract infection were positive for $b l a_{\mathrm{SHV}}$, $b l a_{\mathrm{CTX}-\mathrm{M}-15}$ and $b l a_{\mathrm{TEM}}$ genes, respectively [41]. Furthermore, $20 \%$ of the isolates were carrying $b l a_{\mathrm{KPC}}$ gene.

Bina et al. reported that the resistance rates of $K$. pneumoniae isolates were $15.5 \%, 13.9 \%, 14.5 \%, 50 \%, 44.2 \%$, $36.4 \%, 20.9 \%, 50 \%, 41.3 \%, 60.6 \%$ and $48.8 \%$ against ETP, IPM, MER, CTX, CAZ, FEP, cefoxitin, CRO, GM, piperacillin and aztreonam, respectively. Beside, their results indicated that the $b l a_{\mathrm{KPC}}$ gene was not detected in any of the 41 CRKP isolates, while in phenotypic screening test for $\mathrm{KPC}, 80 \%$ of these isolates were positive. Regarding to these cases and restrictions mentioned about phenotypic methods, researchers rely on molecular-based techniques to confirm phenotypic results [42]. Also, the discrepancy could be due to at least one extendedspectrum cephalosporin and another mechanism such as an ESBL or AmpC-type enzyme with porin loss [43, 44]. An exciting point in our study is the low prevalence of $b l a_{\text {NDM }}$ gene. According to the findings of Fallah et al., the close distance of India and Pakistan to Iran, the large number of journeys between the countries, and the ease of resistance transfer among microorganisms have led us to think that it may be likely for antibiotic-resistant bacteria to have the same gene [45].

PCR test results showed that intI gene was detected in $58 \%$ of the isolates (53 MDR and 5 non-MDR). Concordance with our study, Derakhshan et al. showed that $25.8 \%(8 / 31)$ of their K. pneumoniae isolates were carried intI. In addition, they did not find class II and III integrons [46]. In contrast, Haddadi et al. (2019), found that the class I integron gene frequency among 54 MDR K. pneumoniae clinical strains was $37.6 \%$ [47]. Firoozeh et al. showed that $100 \%(150 / 150)$ and $36.7 \%(55 / 150)$ of their MDR K. pneumoniae carried intI and intII genes, respectively [48]. But this finding is contradictory to our reports. We did not find any class II and III integrons among all samples. This discrepancy could be due to differences in the source of samples, microbial genetic diversity and level of hygiene.

\section{Conclusion}

This study has the potential to add to the body of literature regarding to MDR and/or XDR organisms in Iran. MDR K. pneumoniae is becoming a severe problem in hospitals, as many strains are developing resistance to most available antimicrobials. The increasing rate of these isolates emphasizes the importance of choosing an appropriate antimicrobial regimen based on antibiotic susceptibility patterns. The finding of the present study exposed a high prevalence of class I integron among MDR K. pneumoniae isolates and resistance genes especially $b l a_{\mathrm{SHV}}$ and $b l a_{\mathrm{TEM}}$ from Sari (north of Iran), which led to more attention to MDR strains.

\section{Abbreviations}

BAL: Bronchoalveolar lavage; UTIs: Urinary tract infections; MDR: Multidrugresistant; XDR: Extensively drug-resistant; DD: Disk agar diffusion; PCR: Polymerase chain reaction; CLSI: Clinical laboratory standards institute; QC: Quality control; CSF: Cerebrospinal fluid; BLAST: Basic local alignment search tool; NCBI: National Center for Biotechnology Information; EUCAST: European Committee on Antimicrobial Susceptibility Testing; LB: Luria-Bertani; ECDC: European Center for Disease Control and Prevention; ESBLs: Extended spectrum $\beta$-lactamases; IRKP: IMP-resistant K. pneumonia; CRKP: Carbapenem-resistant $K$. pneumonia; MBLs: Metallo- $\beta$-lactamases; KPC: K. pneumoniae Carbapenemase; NICU: Neonatal intensive care unit; ICUs: Intensive care units.

\section{Supplementary Information}

The online version contains supplementary material available at https://doi. org/10.1186/s12941-021-00476-1.

Additional file 1: Table S1: Primer sequences used for PCR amplification in this study and amplicon sizes.

\section{Acknowledgements \\ Thanks to Department Microbiology and Virology of Mazandaran Univer- sity of Medical Sciences and Antimicrobial Resistance Research Center of Mazandaran University of Medical Sciences for their contribution to this research.}

\section{Authors' contributions}

MG: Design of the study and supervision. MF: collected the data, cultured the samples and performed experiments. MA Advisor in the study and contributed to the analysis of the data in collaboration with HG. MH: Assisted in molecular examinations and edited the manuscript. MG drafting of the manuscript in collaboration with MF. All authors read and approved the final manuscript.

\section{Funding}

This work was done within the Department of Microbiology and Virology of Mazandaran University of Medical Sciences (MAZUMS), Sari, Iran. Also the hospitals of mentioned in our study affiliated by MAZUMS. This work was financially supported by MAZUMS with Grant No. 4950.

\section{Availability of data and materials}

All data generated or analyzed during this work are included in this published article. Also the all data used to support the findings of this study are available from the corresponding author upon request.

\section{Declarations}

Ethics approval and consent to participate

The study was approved by the ethical committee of Mazandaran University of Medical Sciences, Sari, Iran (IR.MAZUMS.REC.1398.628).

Consent for publication

Not applicable.

\section{Competing interests}

The authors declare that they have no competing interests.

\section{Author details}

${ }^{1}$ Department of Microbiology and Virology, Faculty of Medicine, Mazandaran University of Medical Sciences, Sari, Iran. ${ }^{2}$ Antimicrobial Resistance Research 
Center, Communicable Diseases Institute, Mazandaran University of Medical Sciences, Sari, Iran.

\section{Received: 19 February 2021 Accepted: 21 September 2021} Published online: 28 September 2021

\section{References}

1. Russo TA, Marr CM. Hypervirulent Klebsiella pneumoniae. Clin Microbiol Rev. 2019;32(3).

2. Yu VL, Hansen DS, Ko WC, Sagnimeni A, Klugman KP, von Gottberg A, et al. International Klebsiella Study Group: Virulence characteristics of Klebsiella and clinical manifestations of K. pneumoniae bloodstream infections. Emerg Infect Dis. 2007;13:986-93.

3. Davarcı I, Şenbayrak S, Aksaray S, Koçoğlu M, Kuşkucu M, Samastı M. Molecular epidemiology of carbapenem-resistant Klebsiella pneumoniae Isolates. Anatol Clin. 2019;24(1):1-7.

4. Sawatwong P, Sapchookul P, Whistler T, Gregory CJ, Sangwichian O, Makprasert S, et al. High burden of extended-spectrum $\beta$-lactamaseproducing Escherichia coli and Klebsiella pneumoniae bacteremia in older adults: a seven-year study in two rural Thai Provinces. Am J Trop Med Hyg. 2019;100(4):943-51.

5. Shnaiderman-Torban A, Paitan $Y$, Arielly H, Kondratyeva $\mathrm{K}$, Tirosh-Levy S, Abells-Sutton G, et al. Extended-spectrum $\beta$-lactamase-producing Enterobacteriaceae in hospitalized neonatal foals: prevalence, risk factors for shedding and association with infection. Animals. 2019;9(9):600.

6. Livermore DM, Brown DF. Detection of $\beta$-lactamase-mediated resistance. J Antimicrob Chemother. 2001:48(Suppl_1):59-64.

7. Papp-Wallace KM, Endimiani A, Taracila MA, Bonomo RA. Carbapenems: past, present, and future. Antimicrob Agents Chemother. 2011;55(11):4943-60.

8. Reyes JA, Melano R, Cárdenas PA, Trueba G. Mobile genetic elements associated with carbapenemase genes in South American Enterobacterales. Braz J Infect Dis. 2020;24(3):231-8.

9. Stokes HW, Gillings MR. Gene flow, mobile genetic elements and the recruitment of antibiotic resistance genes into Gram-negative pathogens. FEMS Microbiol Rev. 2011;35(5):790-819.

10. Bostanghadiri N, Ghalavand Z, Fallah F, Yadegar A, Ardebili A, Tarashi S, et al. Characterization of phenotypic and genotypic diversity of Stenotrophomonas maltophilia strains isolated from selected hospitals in Iran. Front Microbiol. 2019;10:1191

11. Rowe-Magnus DA, Mazel D. The role of integrons in antibiotic resistance gene capture. Int J Med Microbiol. 2002;292(2):115-25.

12. Feizabadi MM, Mahamadi-Yeganeh S, Mirsalehian A, Mirafshar SM, Mahboobi M, Nili F, et al. Genetic characterization of ESBL producing strains of Klebsiella pneumoniae from Tehran hospitals. J Infect Dev Ctries. 2010;4(10):609-15.

13. Mehrgan H, Rahbar M, Arab-Halvaii Z. High prevalence of extendedspectrum beta-lactamase-producing Klebsiella pneumoniae in a tertiary care hospital in Tehran. Iran J Infect Dev Ctries. 2010:4(03):132-8.

14. Eftekhar F, Naseh Z. Extended-spectrum $\beta$-lactamase and carbapenemase production among burn and non-burn clinical isolates of Klebsiella pneumoniae. Iran J Microbiol. 2015;7(3):144.

15. Ahanjan M, Naderi F, Solimanii A. Prevalence of Beta-lactamases genes and antibiotic resistance pattern of Klebsiella pneumoniae isolated from teaching hospitals, Sari, Iran, 2014. J Mazandaran Univ Med Sci. 2017;27(149):79-87.

16. Mahon CR, Lehman DC, Manuselis G. Textbook of diagnostic Microbiology-E-Book. Elsevier Health Sciences; 2018.

17. Holmes B, Willcox WR, Lapage SP. Identification of Enterobacteriaceae by the API 20E system. J Clin Pathol. 1978;31(1):22-30.

18. CLSI. Performance Standards for Antimicrobial Susceptibility Testing. 28th ed. CLSI supplement M100. Wayne, PA: Clinical and Laboratory Standards Institute; 2018.

19. Basak S, Singh P, Rajurkar M. Multidrug resistant and extensively drug resistant bacteria: a study. J Pathog. 2016;2016:4065603.

20. The European Committee on Antimicrobial Susceptibility Testing. Breakpoint tables for interpretation of MICs and zone diameters. Version 8.0, 2018. http://www.eucast.org.
21. Bass L, Liebert CA, Lee MD, Summers AO, White DG, Thayer SG, et al. Incidence and characterization of integrons, genetic elements mediating multiple-drug resistance, in avian Escherichia coli. Antimicrob Agents Chemother. 1999;43(12):2925-9.

22. Hall RM, Collis CM. Mobile gene cassettes and integrons: capture and spread of genes by site-specific recombination. Mol Microbiol. 1995;15(4):593-600

23. Goldstein C, Lee MD, Sanchez S, Hudson C, Phillips B, Register B, et al. Incidence of class 1 and 2 integrases in clinical and commensal bacteria from livestock, companion animals, and exotics. Antimicrob Agents Chemother. 2001;45(3):723-6.

24. Sidjabat HE, Paterson DL, Adams-Haduch JM, Ewan L, Pasculle AW, Muto CA, et al. Molecular epidemiology of CTX-M-producing Escherichia coli isolates at a tertiary medical center in western Pennsylvania. Antimicrob Agents Chemother. 2009;53(11):4733-9.

25. Cao V, Lambert T, Nhu DQ, Loan HK, Hoang NK, Arlet G, et al. Distribution of extended-spectrum $\beta$-lactamases in clinical isolates of Enterobacteriaceae in Vietnam. Antimicrob Agents Chemother. 2002:46(12):3739-43.

26. Lin SP, Liu MF, Lin CF, Shi ZY. Phenotypic detection and polymerase chain reaction screening of extended-spectrum $\beta$-lactamases produced by Pseudomonas aeruginosa isolates. J Microbiol Immunol Infect. 2012:45(3):200-7.

27. Tenover FC, Kalsi RK, Williams PP, Carey RB, Stocker S, Lonsway D, et al. Carbapenem resistance in Klebsiella pneumoniae not detected by automated susceptibility testing. Emerg Infect Dis. 2006;12(8):1209.

28. Beyrouthy R, Robin F, Cougnoux A, Dalmasso G, Darfeuille-Michaud A, Mallat $\mathrm{H}$, et al. Chromosome-mediated OXA-48 carbapenemase in highly virulent Escherichia coli. J Antimicrob Chemother. 2013;68(7):1558-61.

29. Poirel L, Revathi G, Bernabeu S, Nordmann P. Detection of NDM-1-producing Klebsiella pneumoniae in Kenya. Antimicrob Agents Chemother. 2011;55(2):934-6

30. Yang Y, Higgins CH, Rehman I, Galvao KN, Brito IL, Bicalho ML, et al. Genomic diversity, virulence, and antimicrobial resistance of Klebsiella pneumoniae strains from cows and humans. Appl Environ Microbiol. 2019;85(6):e02654-e2718.

31. Vaez H, Sahebkar A, Khademi F. Carbapenem-Resistant Klebsiella pneumoniae in Iran: a systematic review and meta-analysis. J Chemother. 2019;31(1):1-8

32. Moghadas AJ, Kalantari F, Sarfi M, Shahhoseini S, Mirkalantari S. Evaluation of virulence factors and antibiotic resistance patterns in clinical urine isolates of Klebsiella pneumoniae in Semnan, Iran. Jundishapur J Microbiol. 2018;11(7):1-6.

33. Hou XH, Song XY, Ma XB, Zhang SY, Zhang JQ. Molecular characterization of multidrug-resistant Klebsiella pneumoniae isolates. Braz J Microbiol. 2015;46(3):759-68.

34. Saadatian Farivar A, Nowroozi J, Eslami G, Sabokbar A. RAPD PCR profile, antibiotic resistance, prevalence of armA Gene, and detection of KPC enzyme in Klebsiella pneumoniae isolates. Can J Infect Dis Med Microbiol. 2018:2018:1-7.

35. Jafari Z, Harati AA, Haeili M, Kardan-Yamchi J, Jafari S, Jabalameli F, et al. Molecular epidemiology and drug resistance pattern of carbapenemresistant Klebsiella pneumoniae isolates from Iran. Microb Drug Resist. 2019;25(3):336-43.

36. Karki D, Dhungel B, Bhandari S, Kunwar A, Joshi PR, Shrestha B, et al. Antibiotic resistance and detection of plasmid mediated colistin resistance mcr-1 gene among Escherichia coli and Klebsiella pneumoniae isolated from clinical samples. Gut Pathog. 2021;13(1):1-6.

37. Jamal WY, Albert MJ, Rotimi VO. High prevalence of New Delhi metallo$\beta$-lactamase-1 (NDM-1) producers among carbapenem-resistant Enterobacteriaceae in Kuwait. PLoS ONE. 2016;11(3):e0152638.

38. Cizmeci Z, Aktas E, Otlu B, Acikgoz O, Ordekci S. Molecular characterization of carbapenem-resistant Enterobacteriaceae yields increasing rates of NDM-1 carbapenemases and colistin resistance in an OXA-48-endemic area. J Chemother. 2017:29(6):344-50.

39. Moubareck CA, Mouftah SF, Pál T, Ghazawi A, Halat DH, Nabi A, et al. Clonal emergence of Klebsiella pneumoniae ST14 co-producing OXA-48type and NDM carbapenemases with high rate of colistin resistance in Dubai, United Arab Emirates. Int J Antimicrob Agents. 2018;52(1):90-5.

40. Mahmoudi S, Pourakbari B, Rahbarimanesh A, Abdosalehi MR, Ghadiri $\mathrm{K}$, Mamishi S. An outbreak of ESBL-producing Klebsiella pneumoniae in 
an Iranian referral hospital: Epidemiology and molecular typing. Infect Disord Drug Targets. 2019;19(1):46-54.

41. Ghafourian S, Sekawi Z, Neela V, Khosravi A, Rahbar M, Sadeghifard N. Incidence of extended-spectrum beta-lactamase-producing Klebsiella pneumoniae in patients with urinary tract infection. Sao Paulo Med J. 2012;130(1):37-43.

42. Bina M, Pournajaf A, Mirkalantari S, Talebi M, Irajian G. Detection of the Klebsiella pneumoniae carbapenemase (KPC) in K. pneumoniae Isolated from the Clinical Samples by the Phenotypic and Genotypic Methods. Iran J Pathol. 2015;10(3):199.

43. Goudarzi H, Mirsamadi ES, Ghalavand Z, Vala MH, Mirjalali H, Hashemi A. Rapid detection and molecular survey of bla VIM, bla IMP and bla NDM genes among clinical isolates of Acinetobacter baumannii using new multiplex real-time PCR and melting curve analysis. BMC Microbiol. 2019;19(1):122.

44. Pournajaf A, Rajabnia R, Razavi S, Solgi S, Ardebili A, Yaghoubi S, et al. Molecular characterization of carbapenem-resistant Acinetobacter baumannii isolated from pediatric burns patients in an Iranian hospital. Trop J Pharm Res. 2018;17(1):135-41.
45. Fallah F, Noori M, Hashemi A, Goudarzi H, Karimi A, Erfanimanesh S, et al. Prevalence of blaNDM, blaPER, blaVEB, blaIMP, and blaVIM genes among Acinetobacter baumannii isolated from two hospitals of Tehran, Iran. Scientifica. 2014;2014:245162.

46. Derakhshan S, Peerayeh SN, Fallah F, Bakhshi B, Rahbar M, Ashrafi A. Detection of class 1, 2, and 3 integrons among Klebsiella pneumoniae isolated from children in Tehran hospitals. Arch Pediatr Infect Dis. 2014;2(1):164-8.

47. Haddadi A, Mohammadi R, Harzandi N. Prevalence of integrons as the carrier of multidrug resistance genes among clinical isolates of Klebsiella. J Med Bacteriol. 2019;8(3-4):23-30.

48. Firoozeh F, Mahluji Z, Khorshidi A, Zibaei M. Molecular characterization of class 1, 2 and 3 integrons in clinical multi-drug resistant Klebsiella pneumoniae isolates. Antimicrob Resist Infect Control. 2019;8(1):59.

\section{Publisher's Note}

Springer Nature remains neutral with regard to jurisdictional claims in published maps and institutional affiliations.
Ready to submit your research? Choose BMC and benefit from:

- fast, convenient online submission

- thorough peer review by experienced researchers in your field

- rapid publication on acceptance

- support for research data, including large and complex data types

- gold Open Access which fosters wider collaboration and increased citations

- maximum visibility for your research: over $100 \mathrm{M}$ website views per year

At BMC, research is always in progress.

Learn more biomedcentral.com/submissions 